\title{
Jamaican and Barbadian Health Care Providers' Knowledge, Attitudes and Practices Regarding Emergency Contraceptive Pills
}

\section{By Eileen A. Yam, Georgiana \\ Gordon-Strachan, Garth McIntyre, Horace Fletcher, Sandra G. Garcia, Davida Becker and Enrique Ezcurra}

Eileen A. Yam, now with Abt Associates Inc., Bethesda, MD, USA, was at the Population Council, Mexico City, when this work was done. Georgiana GordonStrachan is lecturer, Department of Epidemiology, and Horace Fletcher is head, Department of Obstetrics, Gynaecology and Child Health, both at University of the West Indies at Mona, Kingston,

Jamaica. Garth McIntyre is lecturer,

University of the West Indies at Cave Hill,

Bridgetown, Barbados. Sandra G. Garcia is director of reproductive health, Population Council, Mexico City.

Davida Becker is a doctoral candidate at Johns Hopkins Bloomberg School of Public Health, Baltimore, MD, USA. Enrique Ezcurra is area manager for the Americas, Department of Reproductive Health and Research, World Health Organization, Geneva.

\begin{abstract}
CONTEXT: Little is known about health care providers' knowledge of, attitudes toward and provision of emergency contraceptive pills in the English-speaking Caribbean, where sexual violence and unplanned pregnancies are persistent public health problems.
\end{abstract}

METHODS: We conducted interviewer-administered surveys of 200 Barbadian and 228 Jamaican pharmacists, general practitioners, obstetrician-gynecologists and nurses in 2005-2006. For each country, Pearson's chi-square tests were used to assess differences in responses among the four provider groups.

RESULTS: Nearly all respondents had heard of emergency contraceptive pills, and large majorities of Barbadian and Jamaican providers had dispensed the method. However, about half had ever refused to dispense it; frequently cited reasons were medical contraindications to use, recent use, method unavailability, safety concerns and being uncomfortable prescribing it. Only one in five providers knew that the method could be safely used as often as needed, and few knew that it was effective if taken within 120 hours of unprotected sexual intercourse. About a quarter of Barbadian and half of Jamaican providers thought the method should be available without a prescription, and half of all providers believed that its use encourages sexual risk-taking and leads to increased STI transmission. Nonetheless, most respondents believed the method was necessary to reduce rates of unintended pregnancy and were willing to dispense it to rape victims, women who had experienced condom failure and women who had not used a contraceptive.

CONCLUSIONS: Future educational efforts among Jamaican and Barbadian health care providers should emphasize the safety and proper use of emergency contraceptive pills, as well as the need to increase the availability of the method. International Family Planning Perspectives, 2007, 33(4):160-167

Emergency contraceptive pills are a postcoital contraceptive method that has been available since the 1970s. ${ }^{1} \mathrm{Nev}-$ ertheless, they are an underutilized option for preventing unwanted pregnancy, partly because knowledge of the method is often lacking, even among health care providers who typically serve as the primary gatekeepers to its access. For example, in a study of Indian paramedical workers, just $3 \%$ were familiar with the concept of emergency contraception; ${ }^{2}$ in a survey of Turkish physicians, midwives and nurses, only $29 \%$ of those familiar with the method correctly identified the period of time after unprotected sexual intercourse in which the method was effective; ${ }^{3}$ and in a recent survey, 39\% of Kuwaiti retail pharmacists had heard of the method. ${ }^{4}$ Furthermore, negative attitudes toward and inaccurate knowledge of the method among health care providers-including pharmacists, physicians and nursescan pose substantial barriers to women's timely access to the pills in the event of unprotected intercourse.

In the English-speaking Caribbean, there is a great need for increased awareness of and access to emergency contraceptive pills. Barbados and Jamaica have high levels of sexual violence and unprotected sexual intercourse, particularly among young people. For example, $57 \%$ of pregnancies in Jamaica are unwanted or unplanned, and 20\% of Jamaican women have experienced forced sexual inter- course. ${ }^{5}$ Because abortion is highly restricted in this country, women with unplanned or unwanted pregnancies often resort to clandestine, unsafe abortions, which are a leading cause of disability and maternal mortality. ${ }^{6}$ There are no comparable reproductive health data for Barbados. Despite the potential for emergency contraceptive pills to dramatically improve the reproductive health of women in the English-speaking Caribbean, little research has been conducted on the method in these countries, particularly in small nations such as Barbados.

Emergency contraceptive pills are sold in pharmacies in both Jamaica and Barbados, but regulations regarding their provision differ. Since June 2003, Postinor-2 (a dedicated levonorgestrel product) has been available in Jamaica without a prescription, under the condition that pharmacists counsel women about the method at the time of purchase. In Barbados, Postinor-2 is also sold in pharmacies, but is legally available only by prescription. We are aware of no previous studies in Barbados on providers' knowledge of, attitudes toward or provision practices regarding the method. Because of the scarcity of information on the provision of emergency contraceptive pills in Caribbean countries, we conducted two surveys with the aim of addressing this research gap among Barbadian and Jamaican health care providers. 


\begin{tabular}{|c|c|c|c|c|c|c|c|c|c|c|}
\hline \multirow[t]{2}{*}{ Characteristic } & \multicolumn{5}{|l|}{ Jamaica } & \multicolumn{5}{|l|}{ Barbados } \\
\hline & $\begin{array}{l}\text { Total } \\
(\mathrm{N}=228)\end{array}$ & $\begin{array}{l}\text { Nurse } \\
(N=30)\end{array}$ & $\begin{array}{l}\mathrm{GP} \\
(\mathrm{N}=94)\end{array}$ & $\begin{array}{l}\text { Ob/gyn } \\
(\mathrm{N}=33)\end{array}$ & $\begin{array}{l}\text { Pharmacist } \\
(\mathrm{N}=71)\end{array}$ & $\begin{array}{l}\text { Total } \\
(N=200)\end{array}$ & $\begin{array}{l}\text { Nurse } \\
(\mathrm{N}=36)\end{array}$ & $\begin{array}{l}\mathrm{GP} \\
(\mathrm{N}=84)\end{array}$ & $\begin{array}{l}\text { Ob/gyn } \\
(\mathrm{N}=6)\end{array}$ & $\begin{array}{l}\text { Pharmacist } \\
(\mathrm{N}=74)\end{array}$ \\
\hline \multicolumn{11}{|l|}{ Sex } \\
\hline Female & 57.5 & 100.0 & 39.4 & 24.2 & 78.9 & 53.5 & 100.0 & 41.7 & 50.0 & 44.6 \\
\hline Male & 42.5 & 0.0 & 60.6 & 75.8 & 21.1 & 46.5 & 0.0 & 58.3 & 50.0 & 55.4 \\
\hline \multicolumn{11}{|l|}{ Age } \\
\hline$<40$ & 23.3 & 24.1 & 6.7 & 16.1 & 47.1 & 38.3 & 5.6 & 41.5 & 33.3 & 51.4 \\
\hline $40-49$ & 32.0 & 48.3 & 30.3 & 29.0 & 28.6 & 27.6 & 22.2 & 26.8 & 0.0 & 33.3 \\
\hline$\geq 50$ & 44.8 & 27.6 & 63.0 & 54.9 & 24.3 & 34.2 & 72.2 & 31.7 & 66.7 & 15.3 \\
\hline \multicolumn{11}{|c|}{ Employment sector } \\
\hline Public & 13.7 & 89.7 & 1.1 & 3.0 & 4.2 & 34.5 & 83.3 & 35.7 & 16.7 & 10.8 \\
\hline Private & 70.5 & 0.0 & 86.2 & 51.5 & 87.3 & 52.0 & 8.3 & 41.7 & 50.0 & 85.1 \\
\hline Both & 15.9 & 10.3 & 12.8 & 45.5 & 8.5 & 13.5 & 8.3 & 22.6 & 33.3 & 4.1 \\
\hline \multicolumn{11}{|c|}{ Discusses family planning with clients } \\
\hline Very often & 58.4 & 93.3 & 50.0 & 96.9 & 37.1 & 50.0 & 75.0 & 47.6 & 100.0 & 36.5 \\
\hline Somewhat often & 19.9 & 6.7 & 21.3 & 3.1 & 31.4 & 21.5 & 8.3 & 25.0 & 0.0 & 25.7 \\
\hline \multicolumn{11}{|c|}{ Not very often/hardly } \\
\hline ever/never & 21.7 & 0.0 & 28.7 & 0.0 & 31.4 & 28.5 & 16.7 & 27.4 & 0.0 & 37.8 \\
\hline Total & 100.0 & 100.0 & 100.0 & 100.0 & 100.0 & 100.0 & 100.0 & 100.0 & 100.0 & 100.0 \\
\hline
\end{tabular}

Notes: Missing data are excluded. GP=general practitioner. Ob/gyn=obstetrician-gynecologist.

\section{METHODS}

From May 2005 to May 2006, we conducted surveys of nurses, general practitioners, obstetrician-gynecologists and pharmacists in Jamaica and Barbados. In Jamaica, we recruited all obstetrician-gynecologists and public-sector nurses from the Kingston metropolitan area, as well as a sample of general practitioners and private-sector pharmacists.* In Barbados, we recruited all nurses, general practitioners, obstetrician-gynecologists and pharmacists practicing in the country. We identified participants from membership lists of professional associations, directories of public and private pharmacies, and Ministry of Health provider directories.

We used the same survey in both countries. The final version comprised 47 questions addressing a wide range of knowledge, attitude and practice issues regarding emergency contraceptive pills. The knowledge questions focused on safety, contraindications to use, time period of effectiveness and mechanism of action. The attitude questions asked whether the method should be available without prescription, whether its availability encourages sexual risk-taking or leads to an increased rate of STI transmission, whether access to emergency contraceptive pills is necessary to reduce unintended pregnancies and whether respondents were willing to provide the method in advance or to clients in a variety of circumstances. Finally, participants were asked about their experience in providing the method, and their reasons for refusing to provide it to a client.

To facilitate participation, field investigators in each country sent a letter of endorsement for the study from the Ministry of Health to all providers. Trained interviewers telephoned providers to schedule a time when they could complete the survey at their respective workplaces; three attempts were made to contact providers selected for the sample. Interviewers obtained written informed consent; participants received no monetary compensation, but were given a CD-ROM on contraception and a fact sheet on emergency contraception. The study protocol and instruments were reviewed and approved by the institutional review boards of the Ministries of Health of Jamaica and Barbados.

We conducted separate analyses for each country. Pearson's chi-square tests (adjusted for finite populations) were used to assess differences in responses among the four types of health care providers in each country. For groups in which we surveyed a sample rather than the full census, we adjusted all statistical tests to account for simple random sampling without replacement, since it is incorrect to use variance estimates that assume such sampling with replacement when a sample comprises a large percentage of the total population (as was the case for all provider populations in this study). All statistical analyses were carried out using Stata Version 8.

\section{RESULTS}

A total of 228 Jamaican providers and 200 Barbadian providers participated in the surveys. In Jamaica, participation rates were 94\% among nurses, $86 \%$ among general practitioners, $83 \%$ among obstetrician-gynecologists and $76 \%$ among pharmacists. Rates were lower in Barbados: Eighty percent among nurses, 61\% among general practi-

*Our sample includes only public-sector nurses because they are more likely than those in the private sector to offer family planning services. We excluded public-sector pharmacists because, in public pharmacies, women generally have already consulted a doctor or nurse and these pharmacists have little role in counseling women about emergency contraceptive pills. We also excluded pharmacists who were exclusively employed by pharmaceutical companies, as these pharmacists have little or no contact with consumers. 
tioners, 43\% among obstetrician-gynecologists and 73\% among pharmacists. Because only six Barbadian obstetrician-gynecologists were surveyed, we present these findings in the tables, but do not discuss them in the text.

In both countries, more than half of the participants were female; all of the nurses were women (Table 1, page 161). Seventy-nine percent of Jamaican pharmacists were female, as were $45 \%$ of Barbadian pharmacists. In Jamaica, a majority of obstetrician-gynecologists (55\%) and general practitioners (63\%) were 50 or older; in Barbados, $72 \%$ of nurses were 50 or older. Seventy-one percent of Jamaican participants worked exclusively in the private sector, as did $52 \%$ of Barbadian participants. A large majority of participants in each country (78\% in Jamaica, $72 \%$ in Barbados) reported that they discussed family planning with clients "somewhat often" or "very often"; higher proportions of nurses and obstetrician-gynecologists than of the other groups said they discussed it "very often."

\section{Knowledge of Emergency Contraceptive Pills}

Nearly all respondents in both countries had heard of emergency contraceptive pills (one Barbadian nurse had notTable 2). However, the majority of participants were unaware of the method's safety, contraindications to use, time period of effectiveness or mechanism of action.
In Jamaica, only one in five respondents knew that the method could be safely used as often as needed; one in four obstetrician-gynecologists knew this (differences were not significant among Jamaican provider groups). Many participants mistakenly believed that there were medical contraindications to using the method. For example, $41 \%$ of obstetrician-gynecologists and $69-78 \%$ of respondents in the other provider groups erroneously stated that thromboembolic disease was a contraindication. Several other contraindications were also cited: being 35 or older and a cigarette smoker by $34 \%$ of all respondents, liver disease by $61 \%$ and breast-feeding by $36 \%$.

Among the 222 Jamaican respondents who knew that the pills were to be taken after unprotected intercourse, the proportion of providers in each group who knew that the method was effective for up to 120 hours was very lowranging from $0-1 \%$ of nurses and pharmacists to $16 \%$ of obstetrician-gynecologists. Overall, $77 \%$ of respondents believed the method was effective up to 72 hours (as stated on the packaging). Although the majority of participants correctly stated that the mechanism of action was pregnancy prevention (68\%), the proportions believing that the method could cause an abortion ranged from 3\% of obstetrician-gynecologists and $4 \%$ of pharmacists to $17 \%$ of general practitioners and $24 \%$ of nurses.

\begin{tabular}{|c|c|c|c|c|c|c|c|c|c|c|}
\hline \multirow[t]{2}{*}{ Measure } & \multicolumn{5}{|l|}{ Jamaica } & \multicolumn{5}{|l|}{ Barbados } \\
\hline & Total & Nurse & GP & Ob/gyn & Pharmacist & Total & Nurse & GP & Ob/gyn & Pharmacist \\
\hline \multicolumn{11}{|l|}{ PERCENTAGES $†$} \\
\hline Ever heard of the method & 100.0 & 100.0 & 100.0 & 100.0 & 100.0 & $99.5^{* * *}$ & 97.2 & 100.0 & 100.0 & 100.0 \\
\hline $\begin{array}{l}\text { Believe method can be safely } \\
\text { used as often as needed } \neq\end{array}$ & 20.3 & 13.3 & 19.8 & 25.0 & 21.7 & $21.3^{* * *}$ & 14.3 & 28.6 & 66.7 & 12.5 \\
\hline \multicolumn{11}{|l|}{ Reported contraindication to use } \\
\hline Age $\geq 35$ and cigarette smoking & $34.3^{* * *}$ & 42.9 & 27.0 & 18.8 & 47.1 & $50.3^{* * *}$ & 74.3 & 40.5 & 33.3 & 51.4 \\
\hline Ever had thromboembolic disease & $70.6^{* * *}$ & 69.0 & 75.8 & 40.6 & 78.3 & 92.0 & 94.3 & 92.9 & 100.0 & 89.2 \\
\hline Ever had liver disease & $60.7^{* * *}$ & 55.2 & 68.5 & 46.9 & 59.4 & 80.4 & 85.7 & 79.8 & 83.3 & 78.4 \\
\hline Currently breast-feeding & $35.8^{* * *}$ & 10.7 & 42.2 & 15.6 & 47.1 & $57.6^{* * *}$ & 60.0 & 39.8 & 50.0 & 77.0 \\
\hline \multicolumn{11}{|c|}{$\begin{array}{l}\text { PERCENTAGE DISTRIBUTIONS§ } \\
\text { No. of hrs. that method is effective after } \\
\text { unprotected sexual intercourset† }\end{array}$} \\
\hline Within 24 & $12.7^{* * *}$ & 13.3 & 21.4 & 6.3 & 4.3 & $29.1^{* * *}$ & 33.3 & 34.2 & 66.7 & 18.3 \\
\hline Within 36 & 0.0 & 0.0 & 0.0 & 0.0 & 0.0 & 0.5 & 0.0 & 0.0 & 0.0 & 1.4 \\
\hline Within 48 & 3.6 & 3.3 & 6.7 & 3.1 & 0.0 & 10.6 & 9.1 & 12.7 & 0.0 & 9.9 \\
\hline Within 72 & 76.9 & 83.3 & 62.9 & 75.0 & 92.9 & 58.2 & 57.6 & 49.4 & 33.3 & 70.4 \\
\hline Within 120 & 5.9 & 0.0 & 7.9 & 15.6 & 1.4 & 1.1 & 0.0 & 2.5 & 0.0 & 0.0 \\
\hline Don't know & 1.0 & 0.0 & 1.1 & 0.0 & 1.4 & 0.5 & 0.0 & 1.3 & 0.0 & 0.0 \\
\hline \multicolumn{11}{|l|}{ Perceived mechanism of action } \\
\hline Prevents pregnancy & $68.4^{* * *}$ & 72.4 & 56.5 & 57.6 & 87.3 & $60.1^{* * *}$ & 77.1 & 54.8 & 50.0 & 58.9 \\
\hline Induces abortion & 2.7 & 3.5 & 5.4 & 0.0 & 0.0 & 14.1 & 11.4 & 13.1 & 33.3 & 15.1 \\
\hline Prevents pregnancy & & & & & & & & & & \\
\hline and induces abortion & 9.3 & 20.7 & 12.0 & 3.0 & 4.2 & 15.2 & 5.7 & 16.7 & 16.7 & 17.8 \\
\hline 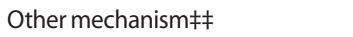 & 17.8 & 0.0 & 23.9 & 36.4 & 8.5 & 9.6 & 2.9 & 14.3 & 0.0 & 8.2 \\
\hline Don't know & 1.8 & 3.5 & 2.2 & 3.0 & 0.0 & 1.0 & 2.9 & 1.2 & 0.0 & 0.0 \\
\hline Total & 100.0 & 100.0 & 100.0 & 100.0 & 100.0 & 100.0 & 100.0 & 100.0 & 100.0 & 100.0 \\
\hline
\end{tabular}


As in Jamaica, surveyed health care providers in Barbados were highly misinformed about the safety, use and mechanism of action of emergency contraceptive pills. Only $21 \%$ of Barbadian respondents knew that the method could be safely used as often as needed, and high proportions erroneously believed that thromboembolic disease (92\%), liver disease ( $80 \%$ ), breast-feeding (58\%), and being 35 or older and a smoker (50\%) were contraindications to use.

Of the 189 Barbadian providers who knew that emergency contraceptive pills should be taken after unprotected intercourse, $29 \%$ believed that it was effective only within the first 24 hours; no nurses or pharmacists were aware that the method was effective for up to 120 hours. Sixty percent of all Barbadian respondents correctly stated that pregnancy prevention was the sole mechanism of action. Nevertheless, $17 \%$ of nurses, $30 \%$ of general practitioners and $33 \%$ of pharmacists cited abortion as a possible mechanism of action.

\section{Attitudes Toward Emergency Contraceptive Pills}

In Jamaica, obstetrician-gynecologists typically expressed the most liberal attitudes toward the method and pharmacists the most conservative attitudes (Table 3). For example, whereas $82 \%$ of the former agreed that the method should be available without prescription, $51 \%$ of pharmacists and general practitioners and 63\% of nurses shared this opinion. And while 16\% of obstetrician-gynecologists somewhat or totally agreed that the method encourages sexual risk-taking, $48 \%$ of general practitioners, $77 \%$ of nurses and $85 \%$ of pharmacists held this opinion. Furthermore, most pharmacists (93\%) believed that the availability of emergency contraceptive pills leads to increased STI transmission, whereas $46-51 \%$ of nurses and general practitioners and only 19\% of obstetrician-gynecologists shared this opinion. A large majority of respondents in each provider group somewhat or totally agreed that the method is necessary to reduce unintended pregnancies (80-97\%), yet support for advance provision varied: Seven percent of nurses and $27 \%$ of pharmacists supported such provision, compared with $57 \%$ of general practitioners and $78 \%$ of obstetrician-gynecologists.

Across provider groups, the large majority of Jamaican participants were willing to provide the pills to rape victims (90\%), women who experienced condom failure (98\%) and women who did not use any method of contraception (93\%). However, support was much lower for providing the method to minors (those younger than 18) without parental consent (66\%), to men requesting it for partners (51\%) and to any woman requesting it, regardless of her circumstances (26\%). Compared with the other provider groups, pharmacists were much less willing to provide the method to minors without parental consent (49\% vs. $69-87 \%$ ) or to any woman who requested it, regardless of circumstances (13\% vs. 28-44\%).

In Barbados, $40 \%$ of pharmacists agreed that emergency contraceptive pills should be available without prescription, while no nurses and only $18 \%$ of general practitioners supported such access. However, 64\% of pharmacists believed that the method encourages sexual risk-taking, compared with $61 \%$ of nurses and $48 \%$ of general practitioners. Similarly, whereas 59\% of pharmacists somewhat

\begin{tabular}{|c|c|c|c|c|c|c|c|c|c|c|}
\hline \multirow[t]{2}{*}{ Measure } & \multicolumn{5}{|l|}{ Jamaica } & \multicolumn{5}{|c|}{ Barbados } \\
\hline & Total & Nurse & GP & Ob/gyn & Pharmacist & Total & Nurse & GP & Ob/gyn & Pharmacist \\
\hline $\begin{array}{l}\text { Method should be available } \\
\text { without prescription }\end{array}$ & $57.0^{* * *}$ & 63.3 & 51.1 & 81.8 & 50.7 & $23.2^{* * *}$ & 0.0 & 17.9 & 33.3 & 40.3 \\
\hline $\begin{array}{l}\text { Method encourages } \\
\text { sexual risk-taking } †\end{array}$ & $59.1^{* * *}$ & 76.7 & 48.4 & 16.1 & 84.5 & $55.1^{* * *}$ & 61.1 & 47.6 & 16.7 & 63.5 \\
\hline $\begin{array}{l}\text { Availability leads to increased } \\
\text { STI transmissiont }\end{array}$ & $59.3^{* * *}$ & 46.2 & 51.1 & 19.4 & 92.8 & $45.9^{* * *}$ & 52.8 & 32.9 & 20.0 & 59.2 \\
\hline $\begin{array}{l}\text { Method is necessary to reduce } \\
\text { unintended pregnancies } †\end{array}$ & $88.3^{* *}$ & 80.0 & 90.1 & 96.9 & 85.7 & $75.3^{*}$ & 61.8 & 79.8 & 83.3 & 75.7 \\
\hline $\begin{array}{l}\text { Willing to provide method } \\
\text { in advance }\end{array}$ & $43.6^{* * *}$ & 6.7 & 56.5 & 78.1 & 26.8 & $7.0^{* *}$ & 8.3 & 8.3 & 16.7 & 4.1 \\
\hline Willing to provide method to & & & & & & & & & & \\
\hline $\begin{array}{l}\text { Rape victims } \\
\text { Women who experienced }\end{array}$ & $90.2^{* * *}$ & 90.0 & 92.5 & 100.0 & 83.1 & $83.8^{* * *}$ & 94.3 & 94.0 & 100.0 & 65.8 \\
\hline $\begin{array}{l}\text { condom failure } \\
\text { Women who did not use }\end{array}$ & $97.8^{*}$ & 93.1 & 97.9 & 100.0 & 98.6 & $88.5^{* * *}$ & 91.7 & 95.2 & 100.0 & 78.4 \\
\hline any contraception & $92.9^{* * *}$ & 80.0 & 93.5 & 100.0 & 94.3 & $70.0^{* * *}$ & 58.3 & 81.0 & 100.0 & 60.8 \\
\hline $\begin{array}{l}\text { Minors without parental consent } \\
\text { Men requesting method for }\end{array}$ & $65.9^{* * *}$ & 69.0 & 69.7 & 87.1 & 49.2 & $29.7^{* * *}$ & 25.0 & 34.9 & 83.3 & 21.6 \\
\hline their partners & $50.9^{* * *}$ & 31.0 & 55.4 & 71.9 & 43.7 & $28.5^{* * *}$ & 13.9 & 15.5 & 33.3 & 50.0 \\
\hline $\begin{array}{l}\text { Any woman regardless of } \\
\text { circumstances }\end{array}$ & $25.8^{* * *}$ & 27.6 & 28.9 & 43.8 & 12.9 & $18.2^{* *}$ & 8.6 & 18.1 & 50.0 & 20.3 \\
\hline
\end{tabular}


or totally agreed that availability of the method leads to increased STI transmission, lower proportions of nurses and general practitioners shared this opinion (53\% and 33\%, respectively). A majority of these three provider groups $(62-80 \%)$ somewhat or totally agreed that the method is necessary to reduce unintended pregnancies, yet only $4-8 \%$ were willing to provide the method in advance.

Majorities of all Barbadian respondents were willing to provide the pills to rape victims, women who experienced condom failure and women who did not use any contraceptives (70-89\%). Although pharmacists were the least willing to provide the method to minors without parental consent (22\%), they were the most supportive of dispensing the method to men who requested it for their partners (50\%). Willingness to provide the method to any woman who requested it, regardless of circumstances, was low among nurses, general practitioners and pharmacists (9-20\%).

\section{Provision Practices of Respondents}

In Jamaica, large majorities of obstetrician-gynecologists, general practitioners and pharmacists reported that a woman had asked them for emergency contraceptive pills (98-100\%) and that they had prescribed or sold the method
(97-100\%; Table 4); lower proportions of nurses reported these experiences (67\% and 63\%, respectively). Of the 212 Jamaican providers who had ever dispensed the method, $8 \%$ had not done so in the previous year, $38 \%$ had dispensed it no more than once a month, 28\% 2-4 times a month and $25 \%$ at least five times a month. Pharmacists were most likely to have dispensed the method at least five times a month over the past year (67\%); in contrast, the majority of respondents in the other three groups had dispensed it no more than once a month (52-63\%).

Forty-seven percent of general practitioners and $61 \%$ of pharmacists had ever refused to sell emergency contraceptive pills, compared with $11 \%$ of nurses and $22 \%$ of obstetrician-gynecologists. Among providers who had ever refused to supply the method, nurses most commonly cited the reason that the method was not available; the most common reasons given by other providers were that the client had a contraindication to use or had recently used the method. Other frequently cited reasons were safety concerns and feeling uncomfortable prescribing the method. About half of all providers who had dispensed it in the last year imposed an age restriction; their mean lower and upper age limits were 15.6 and 41.3 years, respectively.

\begin{tabular}{|c|c|c|c|c|c|}
\hline Measure & Total & Nurse & GP & Ob/gyn & Pharmacist \\
\hline Had a previous experience where a woman asked for method*** & 94.3 & 66.7 & 97.9 & 100.0 & 98.6 \\
\hline Had ever prescribed/sold method ${ }^{* * *}$ & 93.4 & 63.3 & 96.8 & 100.0 & 98.6 \\
\hline \multicolumn{6}{|l|}{ Frequency of providing method in past year***, $\dagger$} \\
\hline Never & 7.6 & 31.6 & 7.8 & 9.4 & 0.0 \\
\hline sonce a month & 37.9 & 63.2 & 52.2 & 53.1 & 5.7 \\
\hline $2-4$ times a month & 28.4 & 5.3 & 33.3 & 31.3 & 27.1 \\
\hline$\geq 5$ times a month & 25.1 & 0.0 & 5.6 & 3.1 & 67.1 \\
\hline Don't remember & 1.0 & 0.0 & 1.1 & 3.1 & 0.0 \\
\hline Total & 100.0 & 100.0 & 100.0 & 100.0 & 100.0 \\
\hline Had ever refused to prescribe/sell method ${ }^{* * *}$ & 43.1 & 10.7 & 46.8 & 21.9 & 60.6 \\
\hline \multicolumn{6}{|l|}{ Reason for refusing to prescribe/sell method\# } \\
\hline Client had contraindication to use ${ }^{* *}, \S$ & 50.5 & 33.3 & 61.9 & 28.6 & 44.2 \\
\hline Client had recently used method*** & 42.6 & 50.0 & 35.7 & 0.0 & 55.8 \\
\hline Had concerns about method safety* & 25.8 & 33.3 & 24.4 & 0.0 & 31.0 \\
\hline Felt uncomfortable prescribing method* & 24.2 & 0.0 & 23.8 & 0.0 & 30.2 \\
\hline Method was not available ${ }^{* * *}$ & 14.7 & 66.7 & 2.4 & 0.0 & 25.6 \\
\hline Religious/moral objection & 8.4 & 0.0 & 9.5 & 0.0 & 9.3 \\
\hline Didn't know enough about method** & 5.3 & 33.3 & 7.1 & 0.0 & 2.3 \\
\hline Other reason $* * *,+\dagger$ & 59.6 & 0.0 & 45.2 & 57.1 & 78.6 \\
\hline Had an age restriction for use of method ${ }^{* * *}, \neq \neq$ & 48.2 & 23.1 & 48.2 & 21.4 & 63.8 \\
\hline \multicolumn{6}{|l|}{ Mean age limit (range) $\neq \ddagger$} \\
\hline Lower & $\begin{array}{l}15.6 \\
(10-18)\end{array}$ & $\begin{array}{l}15.5 \\
(15-16)\end{array}$ & $\begin{array}{l}15.0 \\
(10-18)\end{array}$ & $\begin{array}{l}16 \\
(16-16)\end{array}$ & $\begin{array}{l}16 \\
(12-18)\end{array}$ \\
\hline Upper & $\begin{array}{l}41.3 \\
(32-55)\end{array}$ & $\begin{array}{l}36.0 \\
(32-40)\end{array}$ & $\begin{array}{l}40.7 \\
(35-50)\end{array}$ & $\begin{array}{l}42.8 \\
(40-46)\end{array}$ & $\begin{array}{l}43.2 \\
(35-55)\end{array}$ \\
\hline
\end{tabular}

${ }^{*} p<.05 .{ }^{* *} p<.01 .{ }^{* * *} p<.001$. †Among the 212 respondents who had ever provided the method (19 nurses, 90 general practitioners, 33 obstetrician-gynecologists and 70 pharmacists). $\neq$ Among the 97 respondents who had refused to sell the method previously (three nurses, 44 general practitioners, seven obstetrician-gynecologists and 43 pharmacists). §The most common were hypertension, thromboembolic disease, migraines and pregnancy. ++ The most frequently mentioned were the woman requesting the method too late (i.e., when it was believed to be no longer effective; $24.7 \%$ ), the woman was "abusing" the method ( $6.2 \%$ ) and a man requesting the method (3.1\%). ¥¥Among the 194 respondents who had provided the method in the past year ( 13 nurses, 83 general practitioners, 28 obstetrician-gynecologists and 70 pharmacists). Notes: Missing data are excluded. Statistical comparisons are across provider groups; for the frequency of provision measure, the comparison is across groups and all listed responses. GP=general practitioner. Ob/gyn=obstetrician-gynecologist. 


\begin{tabular}{|c|c|c|c|c|c|}
\hline Measure & Total & Nurse & GP & Ob/gyn & Pharmacist \\
\hline Had a previous experience where a woman asked for method* & 87.9 & 80.0 & 86.9 & 83.3 & 93.2 \\
\hline Had ever prescribed/sold method $* * *$ & 78.5 & 42.9 & 84.0 & 83.3 & 89.0 \\
\hline \multicolumn{6}{|l|}{ Frequency of providing method in past year***, $\dagger$} \\
\hline Never & 16.0 & 28.6 & 17.9 & 0.0 & 12.3 \\
\hline sonce a month & 51.3 & 64.3 & 61.2 & 75.0 & 36.9 \\
\hline $2-4$ times a month & 20.7 & 0.0 & 19.4 & 0.0 & 27.7 \\
\hline$\geq 5$ times a month & 10.0 & 0.0 & 1.5 & 25.0 & 20.0 \\
\hline Don't remember & 2.0 & 7.1 & 0.0 & 0.0 & 3.1 \\
\hline Total & 100.0 & 100.0 & 100.0 & 100.0 & 100.0 \\
\hline Had ever refused to prescribe/sell method $* * *$ & 50.0 & 20.0 & 36.1 & 16.7 & 82.4 \\
\hline \multicolumn{6}{|l|}{ Reason for refusing to prescribe/sell method $\neq$} \\
\hline Client had contraindication to use $\S$ & 27.3 & 42.9 & 36.7 & 100.0 & 19.7 \\
\hline Client had recently used method & 25.3 & 28.6 & 23.3 & 0.0 & 26.2 \\
\hline Had concerns about method safety & 34.3 & 28.6 & 20.0 & 0.0 & 42.6 \\
\hline Felt uncomfortable prescribing method & 49.5 & 28.6 & 23.3 & 0.0 & 65.6 \\
\hline Method was not available & 16.2 & 28.6 & 6.7 & 0.0 & 19.7 \\
\hline Religious/moral objection & 19.2 & 0.0 & 6.7 & 0.0 & 27.9 \\
\hline Didn't know enough about method & 6.1 & 14.3 & 3.3 & 0.0 & 6.6 \\
\hline Other reasontt & 69.7 & 57.1 & 70.0 & 100.0 & 70.5 \\
\hline Had an age restriction for use of method $\neq \neq$ & 45.5 & 66.7 & 42.9 & 33.3 & 45.5 \\
\hline \multicolumn{6}{|l|}{ Mean age limit (range) $\neq \ddagger$} \\
\hline Lower & $\begin{array}{l}16.7 \\
(12-21)\end{array}$ & $\begin{array}{l}16.7 \\
(16-18)\end{array}$ & $\begin{array}{l}16.6 \\
(12-21)\end{array}$ & $18 \S \S$ & $\begin{array}{l}16.7 \\
(14-20)\end{array}$ \\
\hline Upper & $\begin{array}{c}39.5 \\
(30-55)\end{array}$ & $\begin{array}{l}41 \\
(40-45)\end{array}$ & $\begin{array}{l}38.1 \\
(30-45)\end{array}$ & $35 \S \S$ & $\begin{array}{l}41 \\
(30-55)\end{array}$ \\
\hline
\end{tabular}

${ }^{*} \mathrm{p}<.05 .{ }^{* * *} \mathrm{p}<.001$. †Among the 153 respondents who had ever provided the method ( 15 nurses, 68 general practitioners, five obstetrician-gynecologists and 65 pharmacists). $¥$ Among the 99 respondents who had refused to sell the method previously (seven nurses, 30 general practitioners, one obstetrician-gynecologist and 61 pharmacists). Because only one obstetrician-gynecologist had refused to provide the method, no statistical tests were conducted. §The most common were thromboembolic disease, cancer, migraines, cardiac problems and pregnancy, and that the provider suspected the woman was pregnant. $++T$ The most frequently mentioned were the woman not having a prescription ( $26.3 \%$ ), the woman requesting the method too late (i.e., when it was believed to be no longer effective; $23.2 \%$ )

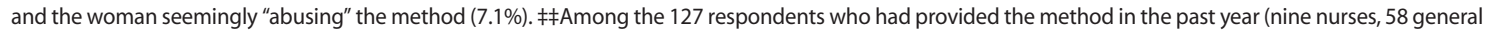
practitioners, four obstetrician-gynecologists and 56 pharmacists). §Only one respondent reported having an age limit. Notes: Missing data are excluded. Statistical comparisons are across provider groups; for the frequency of provision measure, the comparison is across groups and all listed responses. $\mathrm{GP}=\mathrm{general}$ practitioner. Ob/gyn=obstetrician-gynecologist.

Compared to their Jamaican counterparts, Barbadian health care providers as a group less frequently reported ever receiving requests for emergency contraceptive pills (94\% vs. 88\%-Table 5). As in Jamaica, nurses were the least likely of the groups to have received a request ( $80 \%$ vs. $87-93 \%$ of general practitioners and pharmacists) and to have dispensed the method (43\% vs. $84-89 \%$ ). The majority of nurses and general practitioners who had ever provided the method had done so no more than once a month in the previous year (64\% and 61\%), whereas 37\% of pharmacists reported this frequency. Half of all respondents said they had ever refused to dispense the method. For Barbadian pharmacists who had ever refused, the reasons most commonly cited were that they felt uncomfortable prescribing it, they had concerns about its safety and "other" reasons. Common reasons given by nurses and generalpractitioners were that the client had a contraindication to use, the client had recently used the method and, for nurses, the method was not available. Fewer than half of all respondents who had provided the method in the past year imposed an age restriction; their mean lower and upper age limits were 16.7 and 39.5 years, respectively.

\section{DISCUSSION}

We found that levels of awareness of emergency contraceptive pills among health care providers were much higher in Jamaica and Barbados than in such developing countries as Kuwait and India. ${ }^{2,4}$ In addition, the majority of providers interviewed in our study had received a request for the method. Nevertheless, providers demonstrated a substantial lack of specific knowledge regarding the method's safety and use. These findings suggest that although educational and outreach efforts have succeeded in informing providers of the existence of this postcoital contraceptive method, considerable work is needed to clarify common misconceptions and dispel persistent myths. In particular, Jamaican and Barbadian providers need to be educated about the safety of the method, the lack of medical contraindications to its use and the fact that it is effective when taken up to 120 hours after unprotected sexual intercourse. It is encouraging that the majority of respondents in both countries stated that, consistent with Postinor-2 package labeling, the pills are effective up to 72 hours after intercourse. However, it is important that these gatekeepers understand that, according to current research, 
the window of opportunity for women to use the method is even wider.

Although nearly all participants in both Barbados and Jamaica had heard of emergency contraceptive pills, we observed marked differences in attitudes and specific knowledge. For example, Jamaican providers, particularly nurses and general practitioners, expressed greater support than their Barbadian counterparts for method availability without a prescription. This higher acceptance among Jamaican clinicians may simply reflect the fact that, since 2003, clients have been able to obtain the method without a prescription in that country. In contrast, Barbadian clinicians practice in an environment in which emergency contraceptive pills have never been legally available without a prescription. Because a prescription is required, Barbadian providers may have the false impression that a clinical consultation is necessary to rule out possible medical contraindications, thus explaining why many of them erroneously cited contraindications such as thromboembolic and liver disease. Though educational programs and materials targeting providers and the general public often mention that the emergency contraceptive pills contain the same hormones as regular oral contraceptives, future education activities should specify that contraindications to regular birth control pills are not applicable to the emergency method.

In both Jamaica and Barbados, pharmacists and nurses had the most conservative attitudes about the effects of the availability of emergency contraceptive pills on sexual behavior, with the majority in each group claiming that the method encourages sexual risk-taking and leads to increased STI transmission. Although extensive research has consistently shown that use of the method does not lead to decreased use of more effective contraceptive methods or an increase in STI infections, ${ }^{7}$ pharmacists and nurses may be less exposed to the scientific literature and outreach efforts than their physician counterparts. Furthermore, in the year before we began fieldwork in Jamaica, a major national newspaper published articles suggesting that pharmacists were concerned about women "abusing" Postinor2 by substituting it for regular contraceptives. ${ }^{8}$ This negative news coverage may have both reflected and shaped the opinions of Jamaican pharmacists, as more than half of those surveyed who had ever refused to dispense the method said their reason for refusal was that the client had recently used emergency contraceptive pills.

In both countries, nurses' comparatively conservative opinions and unwillingness to provide the method to certain clients may be explained by the fact that they have not been targeted for information or educational efforts, an oversight repeatedly cited by nurse participants who attended our research dissemination meetings. Unlike pharmacists and physicians, nurses do not have the authority to write prescriptions or directly dispense the method, and their "unwillingness" to provide it may simply reflect this situation. That a majority of nurses in both Jamaica and Barbados had received a request for the method further underscores the need to establish mechanisms through which nurses can refer clients to the appropriate venue or provider so that they can receive emergency contraceptive pills in a timely fashion.

Among participants who had ever refused to dispense the method, a minority cited religious or moral reasons for their refusal. Also, resistance to over-the-counter access often focused on the unsubstantiated belief that the method would be abused or that repeated use is unsafe. Therefore, educational messages should highlight the positive aspects of method availability. For example, messages should emphasize the benefits of timely and discreet access to emergency contraceptive pills-particularly for rape victims, to whom a large majority of participants in both countries were willing to provide the method. Barriers such as requiring a prescription or behind-the-counter counseling, or provider unwillingness to offer advance provision, may prevent sexual assault victims from getting the method within the 120-hour period after unprotected intercourse, as women may be unable to obtain a prescription in time or may be too traumatized to speak to a pharmacist for mandatory counseling.

One possible limitation in our findings of support among Jamaican providers for over-the-counter access to emergency contraceptive pills is that we simply asked them whether they supported or opposed such availability without a prescription. However, because a prescription is not necessary in Jamaica, but a "behind-the-counter" pharmacist consultation is theoretically required, this question may not have addressed the relevant issue of removing this counseling requirement. Future surveys on this topic should be designed to reflect and accurately assess providers' opinions on national regulations.

Our findings should be helpful in future outreach efforts to health care providers, as they have identified specific attitudes and knowledge gaps of particular provider groups. Educational programming should be designed to address, for example, Jamaican pharmacists' fears that access increases sexual risk-taking. Similarly, providers across all groups in both countries could benefit from messages that emphasize the distinction between medication abortion and use of emergency contraceptive pills. In addition, researchers should consider conducting local studies on how method availability may affect sexual behavior (such as contraceptive use and number of partners) to give health care providers useful social science evidence that is culturally specific to the reproductive health settings of Jamaica and Barbados.

\section{REFERENCES}

1. Von Hertzen H et al., Low dose mifepristone and two regimens of levonorgestrel for emergency contraception: a WHO multicentre randomized trial, Lancet, 2002, 360(9348):1803-1810.

2. Tripathi R, Rathore AM and Sachdeva J, Emergency contraception: knowledge, attitude, and practices among health care providers in North India, Journal of Obstetrics and Gynaecology Research, 2003, 29(3):142146.

3. Sevil U, Yanikkerem E and Hatipoglu S, A survey of knowledge, attitudes and practices relating to emergency contraception among health workers in Manisa, Turkey, Midwifery, 2006, 22(1):66-77.

4. Ball DE, Marafie $N$ and Abahussain E, Awareness and perceptions of emergency contraception among retail pharmacists in Kuwait, 
Pharmacy World \& Science, 2006, 28(2):101-106.

5. U.S. Centers for Disease Control and Prevention, Highlights from the Jamaica Reproductive Health Survey, 2002-2003, <http://www.cdc .gov/reproductivehealth/Surveys/Jamaica.htm>, accessed July 7, 2006.

6. Pate E, Maternal and child health, in: Health Conditions in the Caribbean, Washington, DC: Pan American Health Organization, 1997, pp. $171 \& 179$.

7. Raymond EG, Trussell J and Polis CB, Population effect of increased access to emergency contraceptive pills: a systematic review, Obstetrics E Gynecology, 2007, 109(1):181-188.

8. Blair L, "Morning after" scare: Postinor 2 abuse worries pharmacists, Jamaica Gleaner Online, Nov. 30, 2003, <http://www.jamaica-gleaner .com/gleaner/20031130/lead/leÏdl.html>, accessed Sept. 27, 2006.

\section{Resumen}

Contexto: Se sabe poco sobre el conocimiento, actitudes y provisión de pildoras de anticoncepción de emergencia por parte de los proveedores de atención a la salud en el Caribe de habla inglesa, en donde la violencia sexual y los embarazos no planeados persisten como problemas de salud pública.

Métodos: Entre 2005 y 2006, condujimos encuestas administradas por entrevistador entre un total de 200 proveedores de salud barbadenses y otros 228 jamaiquinos; los proveedores eran farmacéuticos, médicos generales, obstetras-ginecólogos y enfermeras. Con el fin de valorar las diferencias en las respuestas de los cuatro grupos de proveedores de servicios, se utilizo la prueba Ji cuadrada de Pearson para cada país.

Resultados: Casi todas las personas entrevistadas habian oído hablar de las píldoras de anticoncepción de emergencia; y la gran mayoría de proveedores de servicios barbadenses y jamaiquinos habian distribuido el método. Sin embargo, cerca de la mitad se habia rehusado a distribuirlo alguna vez; las razones frecuentemente citadas fueron las contraindicaciones médicas para su uso, uso reciente, falta de disponibilidad del método, preocupaciones por la seguridad de la paciente y sentirse incómodo por recetarla. Solamente uno de cada cinco proveedores sabia que el método podría usarse con seguridad tan frecuentemente como fuera necesario; y sólo unos cuantos sabían que el método es efectivo si se toma dentro de las 120 horas posteriores a una relación sexual desprotegida. Cerca de una cuarta parte de los proveedores barbadenses y la mitad de los jamaiquinos consideraron que el método debería estar disponible sin receta médica; y la mitad de todos los proveedores creía que su uso alienta la toma de riesgos sexuales y que conduce a una mayor transmisión de ITS. No obstante, la mayoría de las personas entrevistadas consideró que el método era necesario para reducir las tasas de embarazos no deseados y estaban dispuestos a proporcionarlo a víctimas de violación, a mujeres que habían experimentado la falla de condones y a mujeres que no habian usado un anticonceptivo.

Conclusiones: Los futuros esfuerzos educativos para proveedores jamaiquinos y barbadenses deben poner énfasis en la seguridad y uso apropiado de las píldoras de anticoncepción de emergencia, así como en la necesidad de aumentar la disponibilidad del método.

\section{Résumé}

Contexte: La connaissance et les attitudes des prestataires de santé à l'égard de la pilule contraceptive d'urgence et de sa prescription ne sont guère documentées dans la région anglophone des Caraïbes, où la violence sexuelle et les grossesses non planifiées présentent un problème persistant de santé publique.

Méthodes: Nous avons réalisé des enquêtes, menées par des intervieweurs, à la Barbade et en Jamaïque auprès, respectivement, de 200 et 228 pharmaciens, médecins généralistes, gynécologues-obstétriciens et infirmières en 2005-2006. Pour chaque pays, les différences de réponse entre ces quatre groupes de prestataires ont été évaluées par tests chi carré de Pearson.

Résultats: Presque tous les répondants avaient entendu parler de la pilule contraceptive d'urgence et une grande majorité des prestataires barbadiens et jamaicains avaient prescrit la méthode. Près de la moitié avaient cependant refusé de la prescrire, invoquant le plus fréquemment des raisons de contre-indications médicales, d'usage récent, d'indisponibilité de la méthode, de sécurité et d'embarras à l'idée de la prescrire. Un prestataire sur cinq seulement savait que la méthode pouvait être utilisée sans risque aussi souvent que nécessaire; peu étaient conscients de son efficacité dans les 120 heures suivant des rapports sexuels non protégés. Environ un quart des prestataires barbadiens et la moitié des jamaicains estimaient que la méthode devrait être disponible sans ordonnance et, tous prestataires confondus, la moitié pensaient que son usage favorise la prise de risques sexuels et mène à une transmission accrue d'IST. La plupart des répondants estimaient néanmoins la méthode nécessaire à la réduction des taux de grossesse non planifiée et étaient disposés à la prescrire en cas de viol, d'échec du préservatif ou d'absence contraceptive.

Conclusions: Les efforts de sensibilisation futurs auprès des prestataires de santé jamaïcains et barbadiens devront mettre l'accent sur la sécurité et l'usage approprié de la pilule contraceptive d'urgence, de même que sur la nécessité d'en accroître la disponibilité.

\section{Acknowledgments}

This study was made possible by the generous support of the World Health Organization. We are also grateful to the following collaborators for their valuable contributions to this project: Peter Adams, Sarah Adomakoh, William Adu-Krow, Norma Allen, Carlos Chase, Maisha Emmanuel, Paulene Gayle, Jacqueline Gernay, Nicole Gilkes, Amy Grossman, Nicole Hazel, Shelly McFarlane, Tara Mould, Ernest Pate, Francisco Paz and Joy St. John.

Author contact: eileen_yam@abtassoc.com 